\title{
Analytical method development and validation for simultaneous estimation of Fimasartan Potassium Trihydrate and Cilnidipine in synthetic mixture by HPLC for the treatment of hypertension stage-II
}

\author{
Radhika G. Sojitra* (1) and Urvi J. Chotaliya
}

\begin{abstract}
Background: A specific, accurate, precise, robust, and cost-effective HPLC method was developed and validated for quantitative analysis of Fimasartan Potassium Trihydrate and Cilnidipine in fixed-dose combination. The isocratic elution was accomplished by Symmetry $C_{18}$ column $(150 \mathrm{~mm} \times 4.6 \mathrm{~mm}, 5 \mu \mathrm{m})$ at $25^{\circ} \mathrm{C}$. Mobile phase composition is Methanol: Acetonitrile: Potassium Dihydrogen Phosphate buffer $(\mathrm{pH} 3)(60: 05: 35 \% \mathrm{v} / \mathrm{v} / \mathrm{v})$ at a flow rate of $1.0 \mathrm{~mL} / \mathrm{min}$, injection volume $20 \mu \mathrm{L}$ with DAD detection at $240 \mathrm{~nm}$.

Result: Fimasartan Potassium Trihydrate and Cilnidipine were eluted with retention time 2.65 min and 5.51 min respectively. This method was validated as per ICH guideline (Q2 R1). The calibration plots were over the concentration range of $15-90 \mu \mathrm{g} / \mathrm{mL}$ and $2.5-15 \mu \mathrm{g} / \mathrm{mL}$ for Fimasartan Potassium Trihydrate and Cilnidipine with correlation coefficient 0.9992 and 0.9989 respectively. Accuracy was obtained between $99.51-101.65 \%$ and $100.06-101.20 \%$ for Fimasartan Potassium Trihydrate and Cilnidipine respectively. LOD were found to be $0.97 \mu \mathrm{g} / \mathrm{mL}$ and $0.57 \mu \mathrm{g} / \mathrm{mL}$ and $\mathrm{LOQ}$ were found to be $2.95 \mu \mathrm{g} / \mathrm{mL}$ and $1.75 \mu \mathrm{g} / \mathrm{mL}$ for Fimasartan Potassium Trihydrate and Cilnidipine respectively.
\end{abstract}

Conclusion: The results showed that the developed method is reliable for the routine analysis for simultaneous determination of Fimasartan Potassium Trihydrate and Cilnidipine.

Keywords: ICH guideline (Q2 R1), HPLC, Fimasartan Potassium Trihydrate, Cilnidipine, Hypertension, Validation

\section{Background}

Hypertension is defined as a sustained increase in blood pressure $\geq 140 / 90 \mathrm{~mm} \mathrm{Hg}$, a criterion where the risk of hypertension-related cardiovascular disease is high enough to merit medical attention [1]. It is the most common cardiovascular disease. In India, $29.8 \%$ population is suffering from hypertension. A systolic pressure above 140 or a diastolic pressure above 90 . Blood pressure is the lateral pressure exerted by blood on the wall of the blood

*Correspondence: rsojitrapharma@gmail.com

B. K. Mody Government Pharmacy College, Rajkot 360003, Gujarat, India vessel while flowing through it. It's produced due to cardiac output and peripheral resistance [1].

Fimasartan Potassium Trihydrate is chemically, potassium 5-[4'-(\{2-butyl-5[(dimethylcarbamothioyl) methyl]-4-methyl-6-oxo1,6-dihydropyrimidin-1-yl\} methyl)-[1,1'-biphenyl]2-yl]-1H-1,2,3,4-tetrazole-1-ide Trihydrate, is a novel angiotensin II receptor blocker exhibiting potent and selective AT1 receptor blocking activity. The reported solubility found in methanol and Acetonitrile [2]. It is used for the treatment of mild to moderate essential hypertension. Fimasartan was rapidly absorbed following oral administration. Tmax ranged 


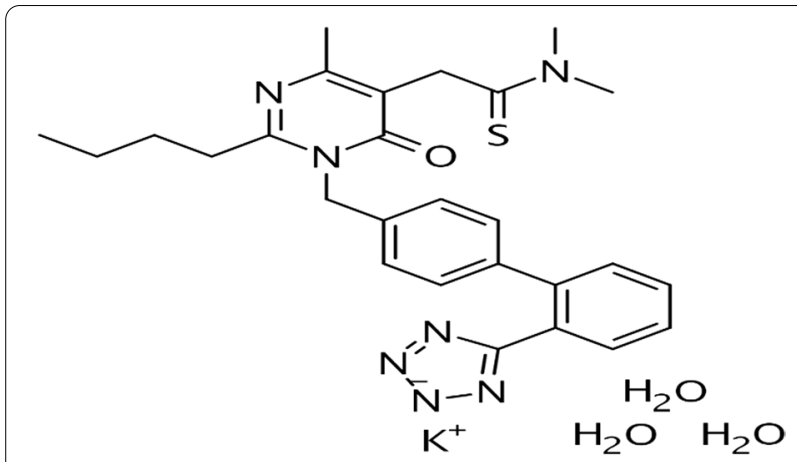

Fig. 1 Chemical Structure of Fimasartan Potassium Trihydrate [2]<smiles>COCCOC(=O)C1=C(C)NC(C)=C(C(=O)OC/C=C/c2ccccc2)C1c1cccc([N+](=O)[O-])c1</smiles>

Fig. 2 Chemical Structure of Cilnidipine [5]

$0.5-3 \mathrm{~h}$ and $t_{1 / 2}$ was $7-10 \mathrm{~h} \mathrm{[2].} \mathrm{The} \mathrm{structure} \mathrm{of} \mathrm{the}$ Fimasartan Potassium Trihydrate is given in Fig. 1.

Cilnidipine, a newer L/N-type Calcium channel blocker, is also an effective antihypertensive. It resolves the amlodipine induced pedel edema while maintaining adequate control of blood pressure [3]. It is chemically, 3-(2-methoxyethyl) 5-(2E)-3-phenylprop-2-en-1-yl 2, 6-dimethyl-4-(3-nitrophenyl)-1, 4-dihydropyridine-3, 5-dicarboxylate. The reported solubility found in Acetonitrile and methanol [4]. Cilnidipine is used along with proper diet and regular exercise to control high blood pressure. Cilnidipine presents a very rapid absorption with a maximum peaked concentration after $2 \mathrm{~h}$. Its distribution tends to be higher in the liver as well as in kidneys, plasma and other tissues [5]. The structure of the Cilnidipine is given in Fig. 2.

A review of the literature reveals that various analytical methods are available for the estimation of individual drugs. It includes UV spectrophotometry [6-8], HPLC $[9,10]$, stability-indicating HPLC [11, 12], HPTLC [13], and ESI-LC-MS/MS [14-20]. Based on the literature survey it was found that there is no simple and RP-HPLC method available for simultaneous estimation of Fimasartan Potassium Trihydrate and Cilnidipine in fixed-dose combination.

\section{Methods}

Materials and instrumentation

Fimasartan Potassium Trihydrate was obtained from Ajanta Pharma Limited, Aurangabad. Cilnidipine was also provided by a reputed company. HPLC grades Methanol, Acetonitrile, and Milli Q water were used. All other chemicals were analytical reagent grade. Chromatographic analysis was carried out using an Agilent Technologies HPLC, DAD detector, and EZ Chrome software for data acquisition. A $0.45 \mu \mathrm{m}$ Nylon filter was used for filtration.

\section{Chromatographic condition}

The Methanol, Acetonitrile, and Phosphate buffer $\mathrm{pH}$ 3.0 in the ratio of $60: 05: 35 \% \mathrm{v} / \mathrm{v} / \mathrm{v}$ was used as a mobile phase. The flow rate was maintained at $1.0 \mathrm{~mL} / \mathrm{min}$. The injection volume is kept $20 \mu \mathrm{L}$ and the detection was carried out at $240 \mathrm{~nm}$.

\section{Preparation of standard stock solution}

A standard stock solution of $100 \mu \mathrm{g} / \mathrm{mL}$ for Fimasartan Potassium Trihydrate and Cilnidipine was prepared by using methanol as diluent.

\section{Preparation of working solution of the mixture} of Fimasartan Potassium Trihydrate and Cilnidipine A working solution of $30 \mu \mathrm{g} / \mathrm{mL}$ for Fimasartan Potassium Trihydrate and $5 \mu \mathrm{g} / \mathrm{mL}$ for Cilnidipine were prepared by appropriate dilution.

\section{Calibration standards}

Six standard concentrations with 15, 30, 45, 60, 75 and $90 \mu \mathrm{g} / \mathrm{mL}$ were prepared from the stock solution of Fimasartan Potassium Trihydrate drug powder (pure form). Similarly, six standard strengths with 2.5, 5, 7.5, $10,12.5$ and $15 \mu \mathrm{g} / \mathrm{mL}$ were prepared from the stock solution of Cilnidipine drug powder (pure form).

\section{Preparation of mobile phase}

Prepare a mixture of Methanol, Acetonitrile and Potassium Dihydrogen Phosphate buffer in the volume ratio 60:05:35\% $/ \mathrm{v} / \mathrm{v}$ for method optimization. Mix well and sonicate to degas the mixture. Adjust pH 3.2 with Orthophosphoric acid.

\section{Method validation}

Analytical validation parameters for the analysis of the proposed method were determined according to ICH (Q2 R1) guideline. [21] The parameters such as 
linearity, range, accuracy, precision, specificity, robustness, LOD \& LOQ were performed [21, 22].

\section{System suitability}

The typical values for evaluating system suitability of a chromatographic procedure include the $\mathrm{RSD}<1 \%$, Asymmetry factor $<2$, and Theoretical plates $>2000$. The determination of system suitability of the analytical method was accomplished by assaying three samples of the same strength as Fimasartan Potassium Trihydrate and Cilnidipine. The sample concentration of Fimasartan and Cilnidipine used in this analysis was $30 \mu \mathrm{g} / \mathrm{mL}$ and $5 \mu \mathrm{g} / \mathrm{mL}$ respectively. The retention time, peak area, theoretical plates, and asymmetry factor were evaluated for system suitability.

\section{Linearity}

The linearity response was determined by analysing 06 independent level of calibration curve in the range of $15-90 \mu \mathrm{g} / \mathrm{mL}(15,30,45,60,75 \& 90 \mu \mathrm{g} / \mathrm{mL})$ for FIK and $2.5-15 \mu \mathrm{g} / \mathrm{mL}(2.5,5.0,7.5,10.0,12.5 \& 15.0 \mu \mathrm{g} / \mathrm{mL})$ for CLN.

The plot of mean peak area against concentration was plotted. Correlation coefficient and regression line equations for FIK and CLN were calculated.

\section{Accuracy and precision}

The accuracy of the method was performed in triplicate at three different concentration levels of 50, 100 and $150 \%$ of the targeted concentration of drugs. The accuracy of the method was evaluated by calculating percentage recovery. Repeatability was performed under 6 replicates at the assay concentration of FIK and CLN. Intra-day and inter-day variations of FIK and CLN were performed in triplicate at three different concentration levels of 50, 100, and $150 \%$. Results are expressed in the form of RSD.

\section{Specificity}

Specificity was performed by injecting diluent, placebo and sample solution to check the interference of excipients.

\section{LOD and LOQ}

The limit of detection (LOD) and limit of quantification (LOQ) were calculated by formula as given in ICH (Q2R1).

$$
\begin{aligned}
& \text { LOD }=3.3 \times \text { Standard deviation/Slope } \\
& \text { LOQ }=10 \times \text { Standard deviation/Slope }
\end{aligned}
$$

\section{Robustness}

The robustness of the method was established by introducing small deliberate change in experimental conditions like flow rate, $\mathrm{pH}$ of Mobile phase and Mobile phase composition. The changes made in flow rate $\pm 0.1 \mathrm{~mL} /$ min, for $\mathrm{pH}$ of Mobile phase \pm 0.2 and mobile phase composition $\pm 2 \%$.

\section{Assay}

The combination of Fimasartan Potassium Trihydrate (60 mg) and Cilnidipine (10 mg) (Film Coated Tablet) is approved by CDSCO for clinical Trial Phase-III trial. So, there is no any single marketed pharmaceutical formulation is available.

The sample (synthetic mixture) was analyzed for assay containing $60 \mu \mathrm{g} / \mathrm{mL}$ of FIK and $10 \mu \mathrm{g} / \mathrm{mL}$ of CLN by optimized HPLC method. (conc. or dose ratio is suggested by CDSCO) [23].

\section{Results}

Optimized condition for method development

Various mobile phase compositions, different columns, $\mathrm{pH}$, flow rate were investigated and the best result was achieved on Symmetry $C_{18}(150 \mathrm{~mm} \times 4.6 \mathrm{~mm}, 5 \mu \mathrm{m})$ column with the mobile phase composition was Methanol: Potassium Dihydrogen Phosphate buffer: Acetonitrile $(60: 35: 05 \% \mathrm{v} / \mathrm{v} / \mathrm{v}) \mathrm{pH} 3$ adjusted with OPA. The detection was carried out at $240 \mathrm{~nm}$ with $1.0 \mathrm{~mL} / \mathrm{min}$ flow rate. The retention time of FIK and CLN is 2.65 and $5.51 \mathrm{~min}$ respectively with a total run time of $10 \mathrm{~min}$. The optimized chromatogram and optimized conditions are mentioned in Fig. 3 and Table 1.

\section{System suitability parameter}

The optimized method is acceptable as system suitability parameters are valid as it passed the criteria of acceptability, as shown in Table 2 .

\section{Method validation \\ Linearity}

The calibration curve obtained for FIK and CLN in the range of $15-90 \mu \mathrm{g} / \mathrm{mL}$ and $2.5-15 \mu \mathrm{g} / \mathrm{mL}$ and the correlation coefficient was found to be 0.9992 and 0.9989 respectively. Linearity graph of both the drugs is revealed in Additional file 1: Figs. S1 and S2 and Additional file 2: Table S1.

\section{Accuracy}

This method is accurate as \% Recovery was found in the range of $99.51-101.65 \%$ for FIK, while for CLN it was found to be in the range of $100.06-101.20 \%$ are shown in Tables 3 and 4.

\section{Precision}

Repeatability and intermediate precision express in term of RSD. As RSD was found to be $<2$ indicating the presented method is precise. The results are summarized in 


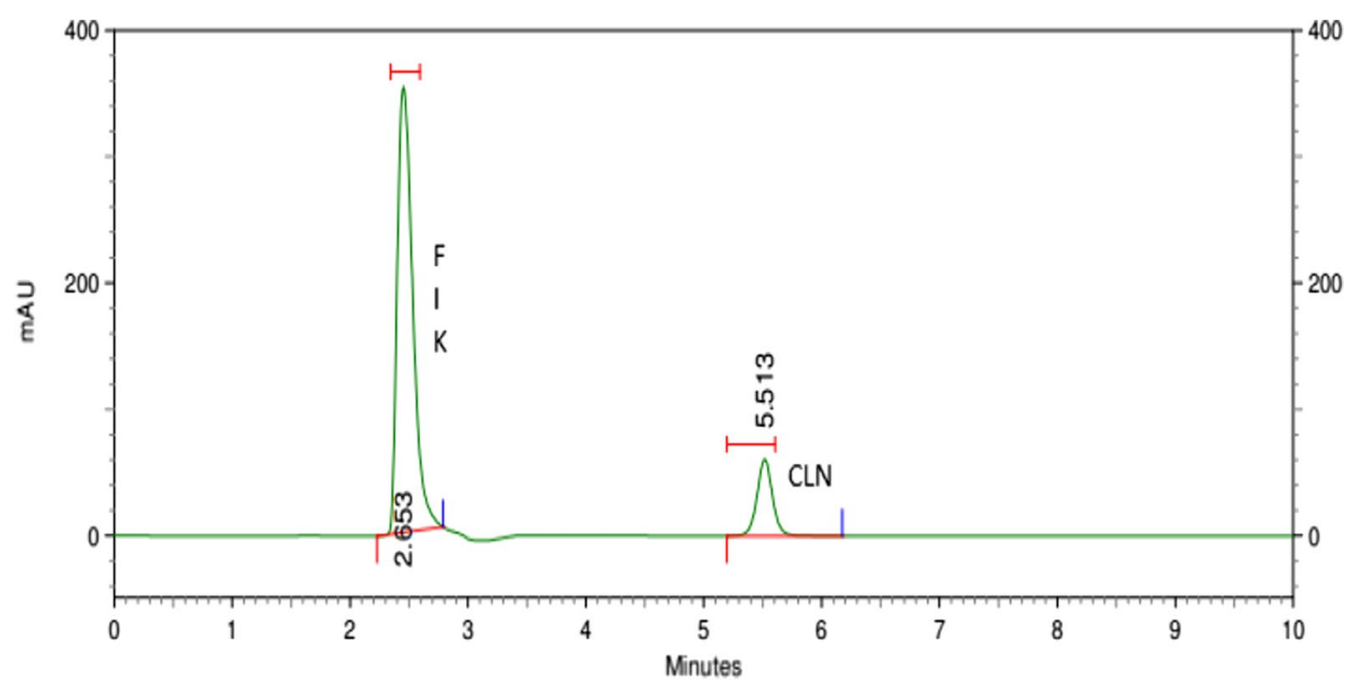

Fig. 3 Optimized chromatogram

Table 1 Optimized chromatographic conditions

\begin{tabular}{|c|c|}
\hline Chromatographic parameters & Optimized condition \\
\hline Column & $\begin{array}{l}\text { Symmetry } C_{18}(150 \mathrm{~mm} \times 4.6 \mathrm{~mm} \text {, } \\
5 \mu \mathrm{m})\end{array}$ \\
\hline Mobile phase & $\begin{array}{l}\text { Methanol: Potassium Dihydrogen } \\
\text { Phosphate buffer: Acetonitrile (60: } \\
\text { 35: } 05 \% \text { v/v/v) } \\
\text { pH } 3 \text { adjusted with OPA }\end{array}$ \\
\hline Flow rate & $1 \mathrm{~mL} / \mathrm{min}$ \\
\hline Temperature & $25^{\circ} \mathrm{C}$ \\
\hline Injection volume & $20 \mu \mathrm{L}$ \\
\hline Detection wavelength & $240 \mathrm{~nm}$ \\
\hline Diluent & Methanol \\
\hline Run time & $10 \mathrm{~min}$ \\
\hline Retention time & FIK: 2.65 min. \& CLN: $5.51 \mathrm{~min}$ \\
\hline
\end{tabular}

Table 2 System suitability parameters

\begin{tabular}{llllll}
\hline Peak & $\begin{array}{l}\text { Retention } \\
\text { time }\end{array}$ & Area & $\begin{array}{l}\text { Theoretical } \\
\text { plate }\end{array}$ & Resolution & $\begin{array}{l}\text { Tailing } \\
\text { factor }\end{array}$ \\
\hline FIK & 2.65 & $6,385,171$ & 3179 & 0.000 & 1.57 \\
CLN & 5.51 & $1,057,738$ & 8522 & 12.99 & 0.98 \\
\hline
\end{tabular}

Additional file 2: Tables S2 and S3 respectively for repeatability study and intermediate precision.

\section{Specificity}

Excipients interference is not observed at the working wavelength of $240 \mathrm{~nm}$, as \% Interference was found less than $0.6 \%$ for both drugs. It is proven by comparing chromatogram of blank, Placebo and sample preparation solution; there was no interference of excipients with the peak of FIK and CLN. Thus, the method is Specific. The results are shown in Additional file 1: Figs. S3, S4 \& S5 and Additional file 2: Tables S4 \& S5.

\section{$\angle O D$ and $L O Q$}

LOD and LOQ were found to be $0.97 \mu \mathrm{g} / \mathrm{mL}$ and $2.95 \mu \mathrm{g} / \mathrm{mL}$ for FIK and $0.57 \mu \mathrm{g} / \mathrm{mL}$ and $1.75 \mu \mathrm{g} / \mathrm{mL}$ for CLN respectively.

\section{Robustness}

Making a deliberate change in flow rate, $\mathrm{pH}$ of mobile phase and mobile phase composition were taken place and RSD was found to be less than 2 , specify that the method is robust. Results, presented in Tables 5, 6, and 7 indicate that the selected factors remained unaffected by a small variation of these parameters.

\section{Assay of synthetic mixture}

A synthetic mixture of FIK \& CLN containing $60 \mathrm{mg}$ of FIK and $10 \mathrm{mg}$ of CLN when analysed using the developed method, showed $100.31 \%$ assay for FIK and $100.01 \%$ assay for CLN.

The combination of Fimasartan Potassium Trihydrate and Cilnidipine (Film Coated Tablet) is approved by CDSCO for clinical Phase-III trial. So, there is no any single marketed pharmaceutical formulation is available. The results are tabulated in Table 8 . 
Table 3 Accuracy data for FIK

\begin{tabular}{|c|c|c|c|c|c|c|c|}
\hline Level (\%) & $\begin{array}{l}\text { Target Conc. } \\
(\mu \mathrm{g} / \mathrm{mL})\end{array}$ & $\begin{array}{l}\text { Spiked Conc. } \\
(\mu \mathrm{g} / \mathrm{mL})\end{array}$ & $\begin{array}{l}\text { Total Conc. } \\
(\mu \mathrm{g} / \mathrm{mL})\end{array}$ & Area & $\begin{array}{l}\text { Found conc. } \\
(\mu \mathrm{g} / \mathrm{mL})\end{array}$ & $\%$ Recovery & Mean of $\%$ recovery \\
\hline \multirow[t]{3}{*}{50} & 30 & 15 & 45 & $7,658,077$ & 44.64 & 99.22 & $99.58 \%$ \\
\hline & 30 & 15 & 45 & $7,650,531$ & 44.56 & 99.04 & \\
\hline & 30 & 15 & 45 & $7,711,370$ & 45.21 & 100.48 & \\
\hline \multirow[t]{3}{*}{100} & 30 & 30 & 60 & $9,185,382$ & 61.00 & 101.66 & $101.65 \%$ \\
\hline & 30 & 30 & 60 & $9,217,715$ & 61.34 & 102.24 & \\
\hline & 30 & 30 & 60 & $9,150,944$ & 60.63 & 101.05 & \\
\hline \multirow[t]{3}{*}{150} & 30 & 45 & 75 & $10,455,190$ & 74.59 & 99.46 & $99.51 \%$ \\
\hline & 30 & 45 & 75 & $10,427,399$ & 74.29 & 99.06 & \\
\hline & 30 & 45 & 75 & $10,494,815$ & 75.02 & 100.02 & \\
\hline
\end{tabular}

Table 4 Accuracy data for CLN

\begin{tabular}{|c|c|c|c|c|c|c|c|}
\hline Level (\%) & $\begin{array}{l}\text { Target Conc. } \\
(\mu \mathrm{g} / \mathrm{mL})\end{array}$ & $\begin{array}{l}\text { Spiked Conc. } \\
(\mu \mathrm{g} / \mathrm{mL})\end{array}$ & $\begin{array}{l}\text { Total Conc. } \\
(\mu \mathrm{g} / \mathrm{mL})\end{array}$ & Area & $\begin{array}{l}\text { Found conc. } \\
(\mu \mathrm{g} / \mathrm{mL})\end{array}$ & \% Recovery & Mean of $\%$ recovery \\
\hline \multirow[t]{3}{*}{50} & 5 & 2.5 & 7.5 & $1,298,504$ & 7.57 & 100.94 & $100.06 \%$ \\
\hline & 5 & 2.5 & 7.5 & $1,288,945$ & 7.48 & 99.75 & \\
\hline & 5 & 2.5 & 7.5 & $1,286,759$ & 7.46 & 99.48 & \\
\hline \multirow[t]{3}{*}{100} & 5 & 5 & 10 & $1,567,421$ & 10.07 & 100.71 & $100.57 \%$ \\
\hline & 5 & 5 & 10 & $1,560,685$ & 10.00 & 100.08 & \\
\hline & 5 & 5 & 10 & $1,569,936$ & 10.09 & 100.94 & \\
\hline \multirow[t]{3}{*}{150} & 5 & 7.5 & 12.5 & $1,849,351$ & 12.69 & 101.53 & $101.20 \%$ \\
\hline & 5 & 7.5 & 12.5 & $1,839,108$ & 12.59 & 100.77 & \\
\hline & 5 & 7.5 & 12.5 & $1,845,993$ & 12.66 & 101.28 & \\
\hline
\end{tabular}

Table 5 Result for change in flow rate $( \pm 0.1)$

\begin{tabular}{llllll}
\hline $\begin{array}{llllll}\text { Flow rate } \\
(\mathbf{m L} / \mathbf{m i n})\end{array}$ & FIK & & & CLN & \\
\cline { 6 - 7 } \cline { 6 - 7 } & Mean area \pm SD & RSD & & Mean area \pm SD & RSD \\
\hline $\mathbf{0 . 9}$ & $6,324,955 \pm 5288.73$ & 0.08 & & $1,054,320 \pm 1316.86$ & 0.12 \\
$\mathbf{1 . 0}$ & $6,326,703 \pm 4516.74$ & 0.07 & & $1,057,859 \pm 1406.11$ & 0.13 \\
$\mathbf{1 . 1}$ & $6,327,902 \pm 5043.82$ & 0.07 & & $1,058,142 \pm 1812.43$ & 0.17 \\
\hline
\end{tabular}

Table 6 Result for change in $\mathrm{pH}$ of MP $( \pm 0.1)$

\begin{tabular}{lllllll}
\hline pH of MP & FIK & & & CLN & \\
\cline { 2 - 3 } \cline { 6 - 7 } \cline { 6 - 7 } & Mean area \pm SD & RSD & & Mean Area \pm SD & RSD \\
\hline 2.9 & $6,354,767 \pm 3507.55$ & 0.05 & & $1,056,100 \pm 2605.00$ & 0.24 \\
3.0 & $6,333,506 \pm 2829.62$ & 0.04 & & $1,051,273 \pm 800.39$ & 0.07 \\
3.1 & $6,331,467 \pm 2723.62$ & 0.04 & & $1,051,523 \pm 1399.57$ & 0.13 \\
\hline
\end{tabular}

\section{Discussion}

The present method was developed using Methanol: Acetonitrile: Potassium Dihydrogen Phosphate buffer at $\mathrm{pH}$ 3.0 adjusted with diluted OPA in the ratio of 60:05:35\% $\mathrm{v} / \mathrm{v} / \mathrm{v}$. The method was developed with the minimum
Table 7 Result for change in mobile phase composition $( \pm 2)$

\begin{tabular}{lllllll}
\hline $\begin{array}{llllll}\text { Mobile phase } \\
\text { composition }\end{array}$ & FIK & & & CLN \\
\cline { 2 - 3 } \cline { 6 - 7 } & Mean are $\mathbf{a} \pm$ SD & RSD & & Mean area \pm SD & RSD \\
\hline 58:05:37 & $6,325,438 \pm 4312.18$ & 0.06 & & $1,050,499 \pm 1351.24$ & 0.12 \\
$60: 05: 35$ & $6,326,703 \pm 4516.74$ & 0.07 & & $1,050,768 \pm 1893.69$ & 0.18 \\
$62: 05: 33$ & $6,325,294 \pm 5268.55$ & 0.08 & & $1,049,372 \pm 1721.31$ & 0.16 \\
\hline
\end{tabular}

Table 8 Analysis of synthetic mixture

\begin{tabular}{lll}
\hline Drugs & Conc. $(\mathbf{m g})(\boldsymbol{n}=\mathbf{6})$ & $\begin{array}{l}\text { Mean of } \\
\% \text { assay } \\
(\boldsymbol{n}=\mathbf{6})\end{array}$ \\
\hline $\begin{array}{l}\text { Fimasartan potassium trihy- } \\
\text { drate }\end{array}$ & 60 & 100.31 \\
Cilnidipine & 10 & 100.01 \\
\hline
\end{tabular}

or reduced amount of organic solvents as the mobile phase which results in a more sensitive and cost-effective method. In the present method, Fimasartan Potassium Trihydrate and Cilnidipine were eluted with retention time $2.65 \mathrm{~min}$ and $5.51 \mathrm{~min}$ respectively. On the basis 
of literature survey it was found that there is no method available for simultaneous estimation of Fimasartan Potassium Trihydrate and Cilnidipine in combination.

\section{Conclusion}

A simple, rapid HPLC method was developed for simultaneous determination of Fimasartan Potassium Trihydrate and Cilnidipine in the synthetic mixture, which provides sufficient resolution between both drugs. The developed method was validated by testing its linearity, specificity, accuracy, precision, robustness and results were found within the acceptance limit as per ICH $(\mathrm{Q} 2$ R1) guideline. Statistical analysis proves that the method is suitable for the simultaneous determination of both drugs in pharmaceutical analysis and routine quality control without any interference.

\section{Abbreviations}

HPLC: High-Performance Liquid Chromatography; FIK: Fimasartan Potassium Trihydrate; CLN: Cilnidipine; ACN: Acetonitrile; OPA: Ortho-phosphoric acid; Conc: Concentration; RSD: Relative Standard Deviation; LOD: Limit of Detection; LOQ: Limit of Quantification; DAD: Diode Array Detector.

\section{Supplementary Information}

The online version contains supplementary material available at https://doi. org/10.1186/s43094-021-00336-x.

Additional file 1: Figure S1. The calibration standard curve has been performed for Linearity determination of FIK (Pure Form) in the concentration range $15-90 \mu \mathrm{g} / \mathrm{mL}$. Figure S2. The calibration standard curve has been performed for Linearity determination of CLN (Pure Form) in the concentration range $2.5-15 \mu \mathrm{g} / \mathrm{mL}$. Figure S3. In the Specificity determination, the chromatogram of Blank is performed for the comparison with sample solution. Figure S4. The chromatogram of placebo is performed for the comparison with sample solution for determination of Excipients interference. Figure S5. Excipients interference is not observed at the working wavelength of $240 \mathrm{~nm}$, as \% Interference was found less than $0.6 \%$ for both drugs. It is proven by comparing chromatograms of blank, Placebo and sample preparation solution; there was no interference of excipients with the peak of FIK and CLN.

Additional file 2: Table S1. The calibration curve obtained for FIK in the range of $15-90 \mu \mathrm{g} / \mathrm{mL}$ and the correlation coefficient was found to be 0.9992. Table S2. The calibration curve obtained for CLN in the range of 2.5- $16015 \mu \mathrm{g} / \mathrm{mL}$ and the correlation coefficient was found to be 0.9989 . Table S3. Repeatability study and Intermediate precision has been performed according to guidelines and RSD was found to be $<2$ indicating the presented method is precise. Table $\mathbf{S 4}$. Specificity for FIK has been performed with and without spiking of Placebo; there was no interference of excipients with the peak of FIK. Table S5. Specificity for CLN has been performed with and without spiking of Placebo; there was no interference of excipients with the peak of CLN. Thus, the method is Specific.

\section{Acknowledgements}

The authors are heartly thankful to B. K. Modi Government Pharmacy College, Rajkot, Gujarat, India for providing necessary facilities to carry out the research work. Special thanks to Ajanta Pharma LTD, Aurangabad for providing the drug samples.

\section{Authors' contributions}

The method was performed and validated by RS. Concept and guidance were from UC, and the final manuscript was prepared and checked by RS and UC respectively. We declare that all authors have read and approved the manuscript before submission. All authors read and approved the final manuscript.

Funding

Not applicable.

\section{Declarations}

Ethics approval and consent to participate

Not applicable.

\section{Consent for publication}

Not applicable.

\section{Availability of data and material}

The data for verification is provided with a Supplementary file and the rest of the data, if required, will be available upon request.

\section{Competing interests}

The authors declare that they have no competing interests.

Received: 28 May 2021 Accepted: 28 August 2021

Published online: 16 September 2021

\section{References}

1. Tortora GJ, Grabowski SR (2003) Principles of anatomy and physiology, 10th edn. Wiley, New Jersey, pp 758-759

2. Kim JH, Lee JH, Paik SH, Kim JH, Chi YH (2012) Fimasartan, a novel angiotensin II receptor antagonist. J Arch Pharm Res 35(7):1123-1126

3. Prasad RS (2015) Replacement of Amlodipine with Cilnidipine and assessment of pedal edema along with blood pressure control. Sch J Appl Med Sci 3(4A):1680-1682

4. Merk NJ (2006) In the Merk Index, 14th edn. Royal Society of Chemistry, London, p 2326

5. Drug Profile and Information of Cilnidipine, https://pubchem.ncbi.nlm.nih. gov/compound/CILNIDIPINE. Accessed March 2020

6. Mohammad SS, Avutu SL, Marreddy JL (2019) Development and validated UV method for fimasartan in pure and dosage form. Int J Adv Res Innov Ideas Educ 5(4):1410-1417

7. Agrawal KS, Gnadhi LR (2019) UV spectrophotometric method of fimasartan drug and its tablet formularion. Asian Journal of Pharmaceutical Research and Development 7(5):26-30. https://doi.org/10.22270/ajprd.v7i5.576

8. Ravisankar P (2019) Novel UV and RP-HPLC method for cilnidipine in dosage form. Int J Pharma Sci Res 10(4):1886-1894. https://doi.org/10.13040/IJPSR. 0975-8232.10(4).1886-94

9. Indian Pharmacopoeia (2018) Government of India, Ministry of Health \& Family Welfare, 8th edn. Indian Pharmacopoeia Commission, Ghaziabad, pp 4616-4618

10. Japanese Pharmacopoeia (2017) The Ministry of Health, Labour and Welfare, pp 704-707

11. Pandya CP, Rajput SJ (2017) Validated stability indicating RP-HPLC method for the determination of Fimasartan in presence of degradation products. Indo Am J Pharm Res 7(11):929-946

12. Balakrishna T, Kulkarni A (2020) Development and validation of stability indicating RP-HPLC for estimation of Cilnidipine. J Drug Deliv Ther 10(1):97-100

13. Badade S, Dole M, Wagh V (2019) Development and validation of HPTLC method for fimasartan in bulk and dosage form. Int J Pharmacy Anal Res 8(2):179-184

14. Yoon SH, Oh S, Kim HS (2015) Validated LC-MS/MS Assay for the quantitative determination of Fimasartan in human plasma: application to pharmacokinetic studies. J Chromatog Sci 53(8):1250-1256

15. Kim TH, Shin S, Landersdorfer CB (2015) Population pharmacokinetic modeling of the enterohepatic recirculation of fimasartan in rats, dogs, and humans. AAPS J 17(5):1210-1223 
16. Hyun JY, Kim HJ, Gwon MR (2015) Fully validated ultra-performance liquid chromatography-tandem mass spectrometry method for the determination of Fimasartan in human plasma. J Anal Sci 31(12):1335-1339

17. Kim TH, Kim MG, Shin S, Chi YH (2016) Placental transfer and mammary excretion of a novel angiotensin receptor blocker Fimasartan in rats. BMC Pharmacol Toxicol 17(1):35

18. Zhang X, Zhai S, Zhao R (2006) Determination of Cilnidipine, in human plasma using LC-MS/MS. Anal Chim Acta. https://doi.org/10.1016/j.aca.2006. 11.072

19. Sawaikar L, Kapupara P (2020) Isolation and force degradation products of Ca channel blocker by LC-MS technique. Rasayan J Chem 13(3):1330-1334

20. Lee HW, Seo JH (2008) Development of a LC-ESI/MS method for determination of Cilnidipine in human plasma. J Chromatogr B. https://doi.org/10. 1016/j.jchromb.2007.11.016
21. ICH - Harmonized Tripartite Guideline (2005) Validation of analytical procedures: text and methodology Q2 (R1). In: International conference on harmonization, IFPMA, Geneva, Switzerland

22. Snyder LR, Kirkland JJ, Glajch JL (1997) Practical HPLC method development, 2nd edn. Wiley, New Jersey

23. CDSCO - Drug combination approval (2020) http://www.cdsco.nic.in. Accessed Nov 2021

\section{Publisher's Note}

Springer Nature remains neutral with regard to jurisdictional claims in published maps and institutional affiliations.

\section{Submit your manuscript to a SpringerOpen ${ }^{\circ}$ journal and benefit from:}

- Convenient online submission

- Rigorous peer review

- Open access: articles freely available online

- High visibility within the field

- Retaining the copyright to your article

Submit your next manuscript at $\boldsymbol{\nabla}$ springeropen.com 